\title{
Analisis Biodigester pada Proses Sintesis Biogas dari Sampah Organik Kota Tegal
}

\author{
Joko Setiyono $^{1, \text { a) }}$ dan Silviana Simbolon ${ }^{2}$ \\ ${ }^{I}$ Teknik Mesin, Fakultas Teknik, Universitas Pancasila Jakarta \\ Jl. Borobudur No.7 Menteng, Jakarta Pusat, 10320 \\ ${ }^{2}$ Teknik Mesin, Universitas Pamulang, Jl. Surya Kencana No 1, Tangerang Selatan, 15417

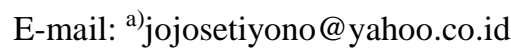

Masuk: 16 Februari 2017 Direvisi : 15 Maret 2017 Disetujui : 27 April 2017

\begin{abstract}
Abstrak: Pada penelitian ini, telah dilakukan analisis biodigester pada proses sintesis biogas dari sampah organik kota tegal. Jenis digester yang digunakan untuk pembuatan biogas adalah jenis kubah tetap dari drum plastik dengan volume 120 liter. Komposisi sampah yang digunakan adalah substrat sayuran 50\%, daun-daunan 20\%, dan kulit buah 30\%. Sampah organik dengan massa sebanyak $\pm 20 \mathrm{~kg}$ dipemerasan/ dipress. Kemudian sampah dan air dicampur dengan perbandingan 1:3. lalu diberikan penambahan starter EM-4 sebanyak $450 \mathrm{ml}$ pada setiap sampel pengujian. Variasi kadar air dalam sampah 10, 20, 30, 40, dan 50\% dengan kompisisi sampah yang sama. Proses pembusukan sampah dan pengambilan data dilakukan selama 3 hari untuk masing-masing variasi kadar air sampah. Dari hasil pengukuran, kondisi optimum terdapat pada kadar air sampah $20 \%$ dalam memproduksi biogas dalam waktu retensi 25 jam pada tekanan 102,55 kPa, suhu $32^{\circ} \mathrm{C}$. dengan volume 95,441 liter.
\end{abstract}

Kata kunci: sampah organik, biodigester, kadar air sampah, biogas

Abstract: In this research, biodigester analysis on biogas synthesis process of organic waste has performed at Tegal city. The digester type which was used for the manufacture of biogas is a fixed dome of plastic drum material with volume of 120 liters. Waste composition which was used as vegetable substrate of 50\%, leaf of $20 \%$, and fruit husk of $30 \%$. Organic waste with mass of $\pm 20 \mathrm{~kg}$ was forged / pressed. The organic waste and water than were mixed with the comparison of 1: 3 . While, The addition of EM-4 starter is amount $450 \mathrm{ml}$ in each test sample. The variation of water content in waste is 10, 20, 30, 40, and $50 \%$ with the same waste composition. The process of waste decomposition and data retrieval were carried out for 3 days for each variation of waste water content. From the measurement result, the optimum condition is reached at $20 \%$ waste water content with 25 hours retention at pressure of $102,55 \mathrm{kPa}$, temperature of $32^{\circ} \mathrm{C}$ and volume of 95,441 liter.

Keywords: organic waste, biodigester, wastewater levels, biogas

\section{PENDAHULUAN}

Sampah adalah segala bentuk limbah yang ditimbulkan dari kegiatan manusia maupun binatang yang biasanya berbentuk padat dan secara umum sudah di buang, tidak bermanfaat atau tidak dibutuhkan lagi. Sampah menjadi persoalan yang cukup serius bagi masyarakat terutama di wilayah perkotaan. Selama ini masyarakat membuang begitu saja sampah ke tempat-tempat sampah dan menyerahkan urusan selanjutnya kepada petugas kebersihan dan urusan selesai. Tetapi sesungguhnya permasalahan tidak selesai sampai di situ. Timbunan sampah di tempat pembuangan akhir menjadi problem tersendiri, problem kesehatan, pencemaran dan keindahan lingkungan [1].

Didalam UU No 18 Tahun 2008 tentang Pengelolaan Sampah, disebutkan sampah adalah sisa kegiatan sehari hari manusia atau proses alam yang berbentuk padat atau semi padat berupa zat organik atau anorganik bersifat dapat terurai atau tidak dapat terurai yang di anggap sudah tidak berguna lagi dan dibuang kelingkungan. Dan UU No. 32 tahun 2009 berisi tentang perlindungan dan pengelolaan lingkungan hidup yang lebih rinci membahas tentang penanganan masalah pengelolaan lingkungan hidup. Pada Pasal 1 perpres RI nomor 18 tahun 2016 sampah juga dapat diubah sebagai sumber energi alternatif [2]. Ketidakpedulian terhadap permasalahan pengelolaan 
sampah mengakibatkan terjadinya degradasi kualitas lingkungan yang tidak memberikan kenyamanan untuk hidup sehingga akan menurunkan kualitas kesehatan masyarakat. Degradasi tersebut lebih terpicu oleh pola perilaku masyarakat yang tidak ramah lingkungan seperti membuang sampah di badan air sehingga sampah akan menumpuk di saluran air yang ada dan menimbulkan berbagai masalah turunan lainnya. Sampah padat, salah satu jenis sampah yang terus menerus meningkat dan dibuang oleh masyarakat [3].

Berdasarkan data dari rencana pembangunan jangka panjang maka sampah yang akan dihasilkan sesuai dengan pertumbuhan penduduk daerah Kabupaten Tegal tahun 2008-2029 [4], volume sampah di TPA Penujah tercatat pada tahun 2015 masyarakat menghasilkan sampah rata-rata $960 \mathrm{~m}^{3} / \mathrm{hari}$ dari volume sampah tersebut kurang lebih 16,87\% merupakan sampah organik dan 83,13\% merupakan sampah anorganik. Produksi sampah ini akan terus meningkat jumlahnya seiring dengan semakin bertambah banyaknya penduduk [5].

Pada penelitian ini dilakukan metoda pengolahan sampah secara terpadu, khususnya di Kab.Tegal dengan teknologi Biodegester. Biodigester salah satu alat yang digunakan untuk mengolah sampah/limbah organik dengan cara fermentasi tanpa oksigen (anaerob) untuk menghasilkan gas metana dan sisa atau limbah akan menjadi pupuk cair maupun padat. Secara prinsip pembuatan biogas sangat sederhana, dengan memasukkan substrat (kotoran hewan, manusia, sampah organik) ke dalam unit pencerna (digester), ditutup rapat, dan selama beberapa waktu biogas akan terbentuk yang selanjutnya dapat digunakan sebagai sumber energi. Penggunaan Biodigester dapat membantu pengembangan sistem pertanian dengan mendaur ulang sampah organik untuk memproduksi biogas dan diperoleh hasil berupa pupuk organik dengan mutu yang baik. Kandungan biogas didominasi oleh gas metana $\left(\mathrm{CH}_{4}\right)$ yang dihasilkan dari proses dekomposisi mikroba pada suatu biomasa. Mikroba tersebut merupakan bakteri pembentuk metana yang banyak terdapat dalam tubuh hewan ruminansia (hewan yang memiliki perut ganda atau rumen) seperti kerbau, sapi, domba, kambing dan lain-lain [8].

Banyak faktor yang mempengaruhi produksi biogas salah satu faktor utamanya adalah iklim, di mana iklim di Indonesia dengan curah hujan yang tinggi akan mempengaruhi kondisi kadar air pada sampah semakin tinggi. Indonesia sendiri beriklim laut tropis karena letaknya di daerah tropis dan diapit oleh dua Samudera yaitu Samudera Pasifik dan Samudera Hindia. Indonesia memiliki dua Musim yaitu musim hujan (Oktober - April), dan musim kemarau (Mei - September).Namun karena wilayahnya yang luas, keadaan geografisnya yang berbedabeda serta daerahnya yang dibelah oleh garis khatulistiwa maka sering terjadi perbedaan atau penyimpangan musim [9]. Kadar air sampah merupakan salah satu sifat fisis sampah. Kadar air menunjukkan kandungan air yang ada dalam sampah. Bahan baku yang paling baik mengandung kadar air $7-9 \%$. Aktifitas mikroba metana membutuhkan bahan dengan kadar air $7-10 \%$ dan $90 \%$ air untuk fermentasi. Penambahan air dalam substrat bertujuan untuk memenuhi kadar air yang disyaratkan untuk pembentukan biogas kurang lebih 91-93\% [10]. Berdasarkan alasan-alasan di atas penelitian ini mengarah tentang peningkatan produksi biogas pada Biodigester dengan pengondisian kadar air dalam sampah. Dengan mengetahui persentase kadar air sampah yang tepat sebagai bahan isian digester, sehingga dapat memproduksi biogas secara optimum.

\section{METODOLOGI}

Proses pembuatan biogas dilakukan menggunakan sistem biodigester dengan bahan sampah organik kota tegal. Data yang diperoleh merupakan hasil dari proses eksperimen pada digester yaitu: kadar air yang terkandung dalam sampah dan kondisi suhu mesophilic, dengan memvariasikan kandungan air sampah. Jenis digester yang digunakan untuk pembuatan biogas adalah jenis kubah tetap dari drum plastik volume 120 liter. Komposisi sampah yang digunakan adalah substrat sayuran 50\%, daun-daunan 20\%, dan kulit buah 30\%. Sampah organik dengan massa sebayak $\pm 20 \mathrm{~kg}$ dipemerasan/ dipress untuk mendapatkan kadar air sampah $100 \%$. Dilakukan proses variasi kadar air dalam sampah 10, 20, 30, 40, dan 50\% liter dengan kompisisi sampah yang sama. Kemudian sampah di campur air dengan komposisi $1 \mathrm{~kg}$ sampah dengan tiga liter air. Kemudian diberikan penambahan starter EM-4 sebanyak $450 \mathrm{ml}$ pada setiap sampel pengujian. Proses pembusukan sampah dan pengambilan data dilakukan selama 3 hari untuk masing-masing variasi kadar air sampah. Setelah didapat kadar air optimum dalam produksi biogas dalam waktu yang cepat maka dilanjutkan penelitian kedua untuk mendapat nyala api dari biogas tersebut. 


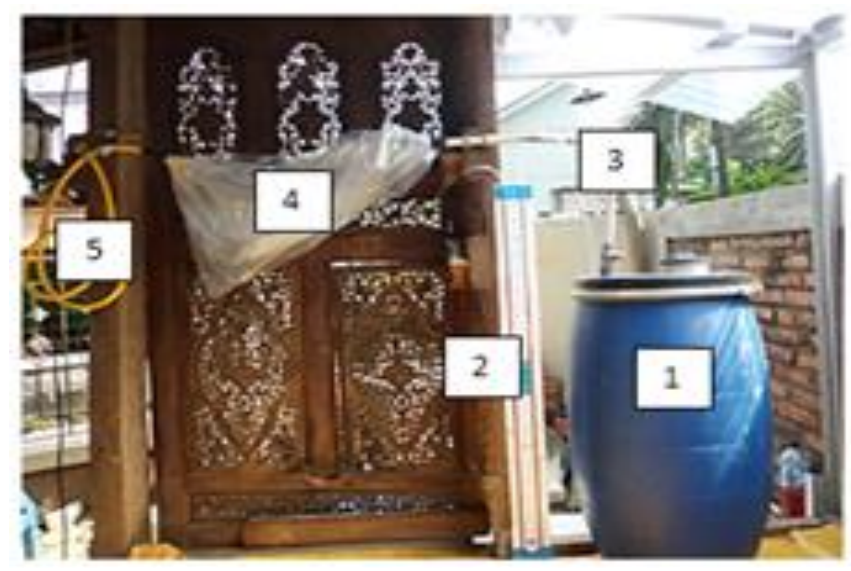

Gambar 1. Instalasi alat penelitian

\section{Keterangan :}

1. Tabung Biodigeter

2. Manometer pipa U

3. Pipa saluran Biogas

4. Gas Holder

5. Saluran Instalasi

\section{HASIL DAN PMBAHASAN}

Dari beberapa kadar air yang diujikan menghasilkan produksi biogas yang berbeda-beda, hal ini dapat dilihat pada Gambar 2. Ketinggian kolom air pada grafik merupakan perubahan tekanan pada penampang alat ukur tekanan manometer, sebagai indikator yang terpasang pada biodigester untuk mengetahui tingkat produksi biogas pada biodigester. Sehingga diketahui kadar air berapa yang mampu memproduksi biogas lebih banyak dan membutuhkan waktu yang relative singkat untuk mencapai titik maksimum.

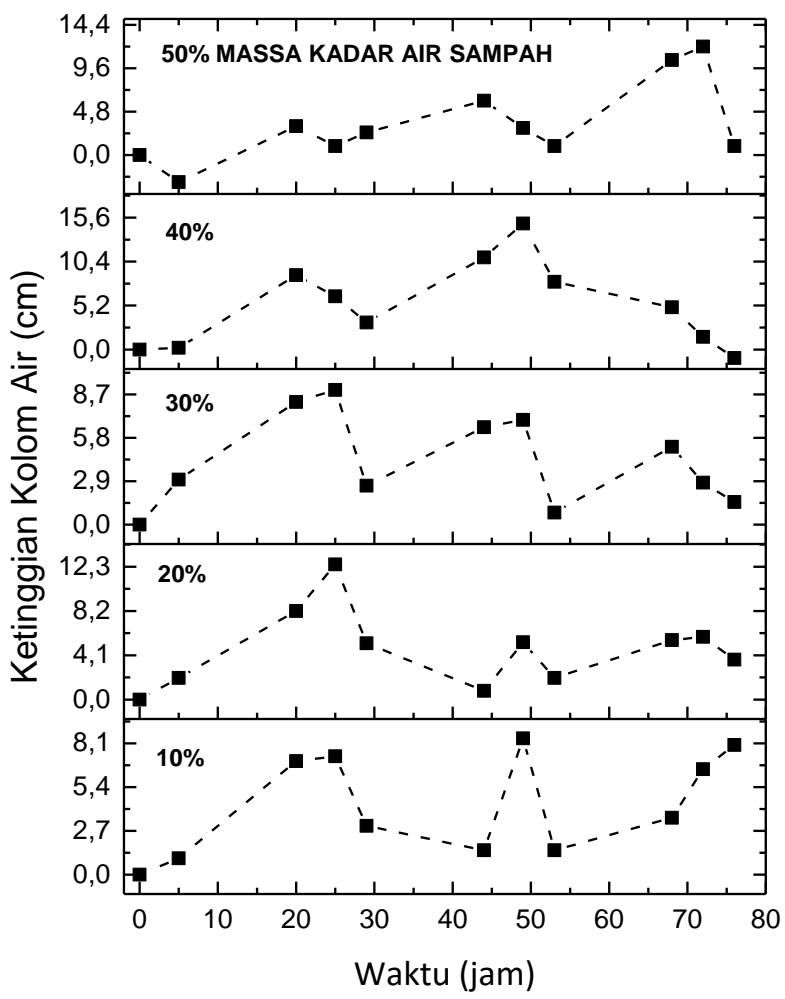

Gambar 2. Hubungan antara waktu dengan ketinggian kolom air dengan kadar air a) 10, b) 20, c) 30, d) 40, dan d) 50\%.

Pada Tabel 1, dapat diketahui bahwa kadar air 10\% mempunyai waktu 24 jam lebih lama dibandingkan kadar air 20\% dengan selisih jumlah produksi 0,4 liter biogas lebih banyak dibanding kadar air 20\%. Pada kadar air $30 \%$ mempunyai waktu retensi yang dengan kadar air 20\%, tetapi jumlah produksi biogas yang dihasilkan lebih sedikit 0,12 liter. Kadar air 40\% mempunyai waktu selisih 24 jam lebih lama dibandingkan kadar air 30\% tetapi produksi biogas lebih banyak 0,54 liter. Kadar air 50\% mempunyai waktu retensi selama 68 jam untuk mencapai hasil yang sama. Dari analisa ini kandungan kadar air sampah 20\% merupakan kondisi dimana produksi biogas paling banyak dengan masa retensi paling cepat . Dimana akan digunakan sebagai acuan penelitian selanjutnya. 
16 | Joko Setiyono, dkk., Analisis Biodigester pada Proses Sintesis Biogas....,

Tabel 1. Produksi optimum biogas setiap variasi kadar air sampah.

\begin{tabular}{cccc}
\hline $\begin{array}{c}\text { Kadar Air Sampah } \\
(\%)\end{array}$ & $\begin{array}{c}\text { Rentang Waktu } \\
(\text { Jam) }\end{array}$ & $\begin{array}{c}\text { Tekanan } \\
(\mathbf{k P a})\end{array}$ & $\begin{array}{c}\text { Volume Biogas } \\
(\text { Liter })\end{array}$ \\
\hline 10 & 49 & 102,49 & 95,066 \\
20 & 25 & 102,55 & 95,441 \\
30 & 25 & 102,20 & 95,121 \\
40 & 49 & 102,78 & 95,660 \\
50 & 68 & 102,35 & 95,258 \\
\hline
\end{tabular}

Pada Gambar 3 diketahui bahwa temperatur lingkungan mempengaruhi tingkat produksi biogas. Temperatur lingkungan sangat mempengaruhi temperatur pada biodigesteryang membantu perkembangan bakteri penghasil biogas yang berada pada kondisi suhu mesophilic $13-40^{\circ} \mathrm{C}$ [11]. Temperatur proses pada masing-masing variasi kadar air saat kondisi puncak produksi berada pada kisaran suhu $30-34{ }^{\circ} \mathrm{C}$. Titik optimum temperatur untuk proses produksi biogas yaitu $32^{\circ} \mathrm{C}$.

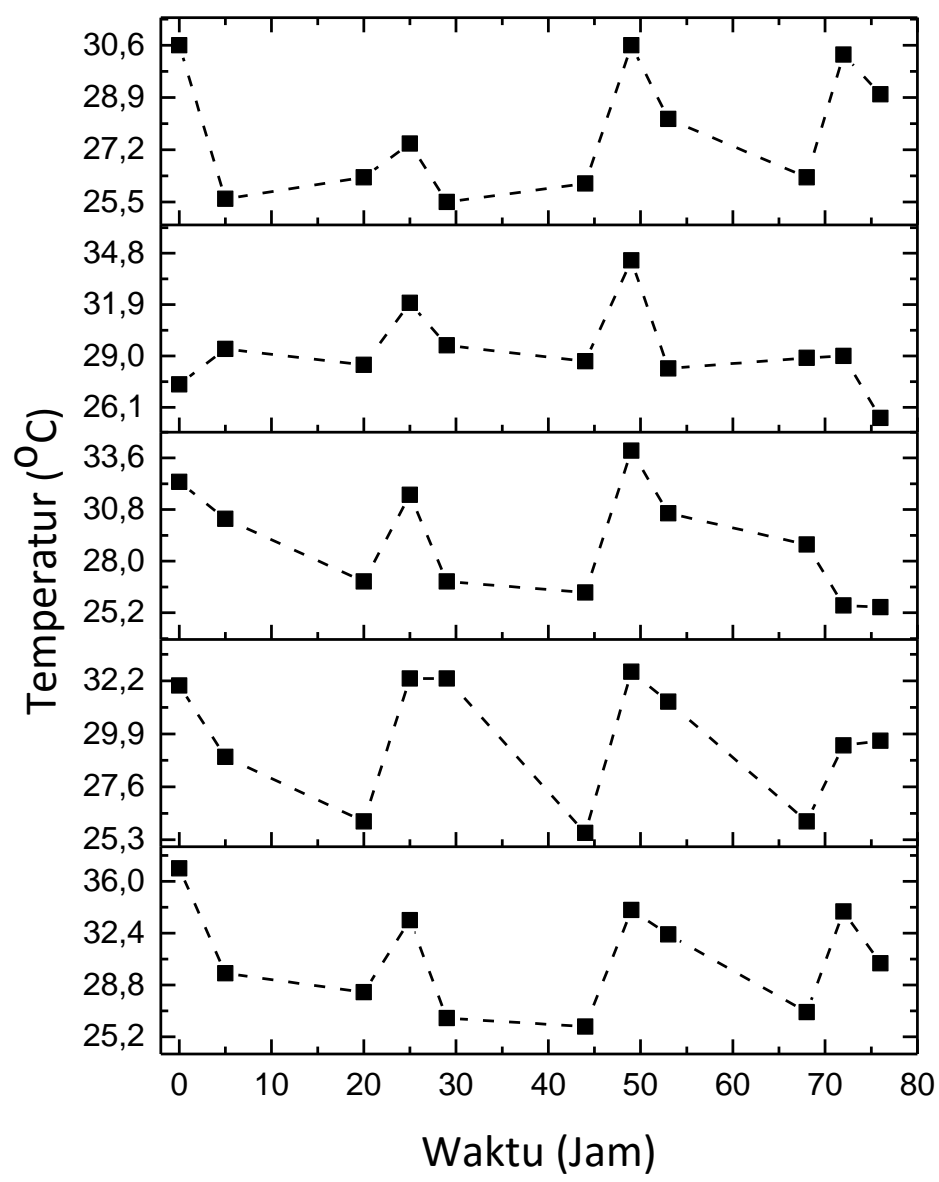

Gambar 3. Hubungan antara temperatur dengan ketinggian kolom air masing-masing untuk kadar air: a) 10\%, b) $20 \%$, c) $30 \%$, dan d) $50 \%$.

Dari Gambar 4 diketahui hasil biogas yang diperoleh dari kandungan sampah pada kadar air $20 \%$ waktu retensi selama 27 hari. Dari hasil yang diperoleh pada tabung digester yang kapasitas substrat 90 liter dengan perbandingan substrat $1 \mathrm{~kg}$ sampah dengan 3 liter air menghasilkan biogas sebanyak 0,0963 $\mathrm{m}^{3}$. Bila dilakukan perhitungan 1 liter substrat (sampah organik + air) dapat menghasilkan biogas 1,071 liter. Hal ini sebabkan karena potensi untuk menghasilkan biogas setiap sampah berbeda-beda walaupun satu jenis sayuran [12]. 


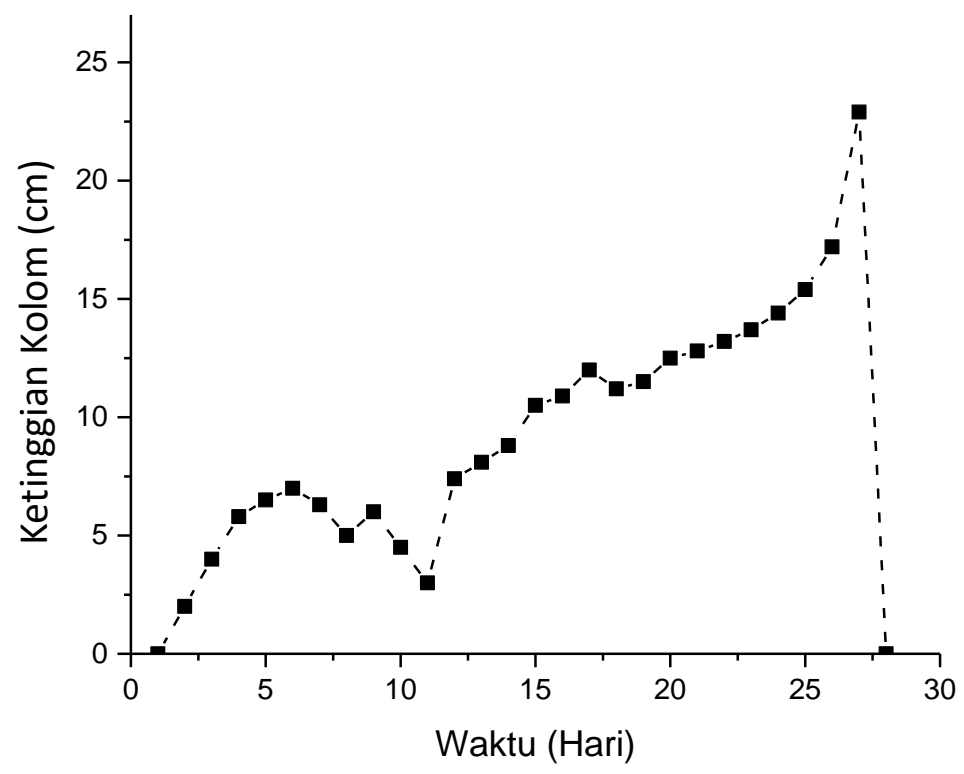

Gambar 4. Hubungan antara masa retensi dengan ketinggian kolom air.

Dari hasil biogas yang terkumpul pada gas holder dilakukan uji coba nyala api yang dijelaskan pada Gambar 5, dengan api yang berwarna kemerahan diperkirakan kandungan $\mathrm{CO}_{2}$ yang terkandung di dalam biogas masih melebihi ambang batas minimum dan tingkat homogenitas substrat sangat mempengaruhi kadar gas yang dihasilkan sehingga nyala api tidak biasa berwarna biru seperti gas LPG.

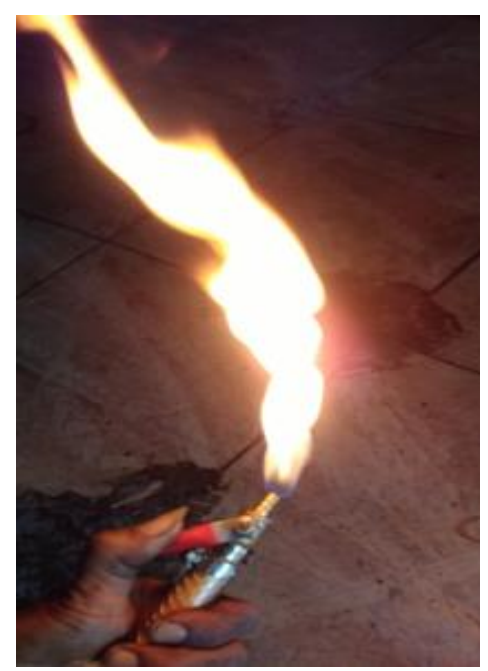

Gambar 5. Pengujian nyala api produksi biogas.

\section{KESIMPULAN}

Telah dilakukan analisis biodigester pada proses sintesis biogas dari sampah organik kota tegal. Jenis digester yang digunakan untuk pembuatan biogas adalah jenis kubah tetap dari drum plastik volume 120 liter. Komposisi sampah yang digunakan adalah substrat sayuran 50\%, daun-daunan 20\%, dan kulit buah 30\%. Dilakukan proses variasi kadar air dalam sampah 10, 20, 30, 40, dan 50\% liter dengan kompisisi sampah yang sama. Dari hasil pengukuran, kadar air sampah $20 \%$ merupakan kondisi optimum dalam memproduksi biogas dalam waktu retensi 25 jam pada tekanan $102,55 \mathrm{kPa}$ dengan volume 95,441 liter. Temperatur lingkungan sangat mempengaruhi fermentasi dari data penelitian masih dalam ambang batas kondisi pertumbuhan bakteri metana dengan kondisi suhu mesophilic antara $13-40{ }^{\circ} \mathrm{C}$ dengan optimum produksi biogas pada suhu $32{ }^{\circ} \mathrm{C}$. 


\section{DAFTAR PUSTAKA}

[1]. Mifbakhuddin, T. Salawati, dan A. Kasmudi, "Gambaran Pengelolaan Sampah Rumah Tangga," Jurnal Kesehatan Masyarakat Indonesia. Semarang, vol. 6, no.1, 2010.

[2]. Undang-undang Republik Indonesia Nomor 18 Tahun 2008 tentang Pengolahan sampah dan Nomor 32 Tahun 2009 tentang Pengelolaan Lingkungan hidup.

[3]. A. Pandie, "Pengelolaan Persampahan dalam Mendukung Perolehan Adipura di Kota Semarang," Jurnal Pembangunan Wilayah dan Kota. Semarang, vol. 9, no. 1, 2013.

[4]. Bappenas Kab.Tegal, Penyusunan revisi penyusunan tata ruang (RT/RW) Kab.Tegal Tahun 2009-2029, Tegal, 2009.

[5]. Departemen Pekerjaan Umum, Bidang Tata Ruang Pertamanan dan Kebersihan, Kab.Tegal, 2015.

[6]. N. Hardyanti dan E. Sutrisnooran, "Uji pembuatan Biogas dari Kotoran Gajah dengan Variasi Penambahan Urine Gajah dan Air,” Jurnal Presipitasi, vol. 3, no. 2, 2007.

[7]. S. Hidayat, 2012, Pusat Pengembangan Bahan Ajar-UMB, (http://dosen.narotama.ac.id). Di akses pada 10 Mei 2016; 22:29.

[8]. P. A. Wiratmana, G K. Sukadana, dan G. N. P.Tenaya, "Studi Eksperimental Pengaruh Variasi Bahan Kering Terhadap Produksi dan Nilai Kalor Biogas Kotoran Sapi," Jurnal Energi dan Manufaktur Teknik Mesin Universitas Udayana, vol. 5, no. 1, 2012.

[9]. T. Saputra, S. Triatmojo, dan A. Pertiwiningrum, "Produksi Biogas dari Campuran Feses Sapi dan Ampas Tebu (Bagasse) dengan Rasio C/N yang Berbeda," Jurnal Buletin Peternakan. vol. 34, no. 2, hal. 114-122, 2010 .

[10]. J. Sutrisno, "Pembuatan Biogas dari Bahan Sampah Sayuran”, Jurnal Teknik Waktu. vol. 08, no. 1, 2010.

[11]. I. Karaman, F. Sahin , M. Güllüce, H. Ögütçü , M. ,Sengül, A. Adigüzel, "Antimicrobial activity of aqueous and methanol extracts of Juniperus oxycedrus L," Journal of Ethnopharmacology, vol. 85, hal. 231-235, 2003.

[12]. BSNI 7826, Unit Penghasil Biogas Dengan Tangki Pencerna tipe Kubah tetap dari beton, Jakarta, 2012. 